\title{
COVID-19: Possible Impact of the Genetic Background in IFNL Genes on Disease Outcomes
}

\author{
Sabine Mihm \\ Department of Gastroenterology and Gastrointestinal Oncology, University Medical Center Göttingen, \\ Göttingen, Germany
}

Dear Editor,

The causative agent of the pandemic COVID-19 outbreak, SARS-CoV-2, is a member of the Coronaviridae family of enveloped viruses with a positive-sense singlestranded (ss) RNA genome [1]. Generally, ssRNA viruses are recognized by the host immune system in first-line defense via innate pattern recognition receptors (PRR), such as Toll-like receptor 7 (TLR7), which is a primary sensor for extracellular or endosomal nucleic acid patterns of viral origin.

Mouse hepatitis corona virus (MHV) is a prototypic $\beta$-genus coronavirus and a well-studied model for SARS$\mathrm{CoV}$. Host control of MHV infection is completely dependent on TLR7 triggering by viral RNA causing an immediate interferon (IFN) response [2]. Similarly, in MERS-CoV infection, a timely IFN signaling has been shown to protect mice from a lethal outcome, i.e., fatal pneumonia [3]. TLR7 is a gonosomal-encoded, $\mathrm{X}$-linked gene. Sex differences in TLR7 responses have been reported for humans - with female sex better coping with viral infection [4-6] - which is also a feature of COVID-19.

\begin{tabular}{ll}
\hline KARGER & ( ) 2020 The Author(s) \\
& Published by S. Karger AG, Basel \\
karger@karger.com & This article is licensed under the Creative Commons Attribution- \\
NonCommercial-NoDerivatives 4.0 International License (CC BY- \\
NC-ND) (http://www.karger.com/Services/OpenAccessLicense). \\
Usage and distribution for commercial purposes as well as any dis- \\
tribution of modified material requires written permission.
\end{tabular}

Upon binding viral nucleic acid motifs, TLR7 induces the expression of type I IFNs (IFN- $\alpha$ and IFN- $\beta$ ) and the expression of the more recently described family of type III IFNs $\left(\right.$ IFN- $\left.\lambda_{1-4}\right)$. During viral infection of lung and liver epithelium, for example, notably, type III IFNs, rather than type I IFNs, are found to be activated [7]. Type III IFNs seem to be the major IFNs induced in airway epithelial cells during infection [7]. Moreover, while type I IFNs act on ubiquitously expressed receptors, type III IFN action is restricted as receptors are particularly expressed on epithelia, e.g., of the lung. Type III IFN induction and its effectors might naturally combat respiratory infections and might constitute a promising therapeutic target pathway.

A common germ line genetic variation within the type III IFN gene locus has been most convincingly shown to determine the host's capacity to cope with an infection induced by hepatitis $\mathrm{C}$ virus (HCV), an enveloped ssRNA virus of positive orientation, too, featuring tropism for liver epithelial cells. One candidate variation is suggested to be a dinucleotide polymorphism within the IFNL4 gene (rs368234815/rs11322783 [TT/ $\Delta \mathrm{G}])$ determining 
the host's capability to encode a functional IFN- $\lambda_{4}$ protein [8]. Paradoxically, the IFNL4 knockout variant TT is favorable for virus eradication and resolution of infection, presumably by the deactivation of an IFN- $\alpha$ desensitizing control mechanism, antagonizing IFN-a efficacy [9].

Globally, the frequency of the favorable knockout variant TT amounts up to 0.841 among Asian populations, which lessens down to 0.689 and 0.293 for individuals of European or African ancestry, respectively. Apart from national measures that unambiguously successfully control viral spread, populations might differ in susceptibility. Moreover, within a given population, individuals might be at different risk, not only due to gender or age [1]. This is to encourage personalizing approaches considering the genetic background in IFNL genes as a hostspecific indicator for the outcome of the prevalent RNA viral infections outside of $\mathrm{HCV}$.

\section{Acknowledgement}

Not applicable.

\section{Disclosure Statement}

The author has no conflicts of interest to declare.

\section{Funding Sources}

This publication is financially supported by the open access publication fund of the University of Göttingen.

\section{Author Contributions}

This is a single author contribution.

\section{References}

1 Zhu N, Zhang D, Wang W, Li X, Yang B, Song J, et al.; China Novel Coronavirus Investigating and Research Team. A Novel Coronavirus from Patients with Pneumonia in China, 2019. N Engl J Med. 2020 Feb;382(8):727-33.

2 Karnam G, Rygiel TP, Raaben M, Grinwis GC, Coenjaerts FE, Ressing ME, et al. CD200 receptor controls sex-specific TLR7 responses to viral infection. PLoS Pathog. 2012;8(5):e1002710.

3 Channappanavar R, Fehr AR, Zheng J, Wohlford-Lenane C, Abrahante JE, Mack M, et al. IFN-I response timing relative to virus replication determines MERS coronavirus infection outcomes. J Clin Invest. 2019 Jul;130(9): 3625-39.
4 Berghöfer B, Frommer T, Haley G, Fink L, Bein G, Hackstein H. TLR7 ligands induce higher IFN-alpha production in females. J Immunol. 2006 Aug;177(4):2088-96.

5 Meier A, Chang JJ, Chan ES, Pollard RB, Sidhu HK, Kulkarni S, et al. Sex differences in the Toll-like receptor-mediated response of plasmacytoid dendritic cells to HIV-1. Nat Med. 2009 Aug;15(8):955-9.

6 Karlberg J, Chong DS, Lai WY. Do men have a higher case fatality rate of severe acute respiratory syndrome than women do? Am J Epidemiol. 2004 Feb;159(3):229-31.
7 Egli A, Santer DM, O'Shea D, Tyrrell DL, Houghton M. The impact of the interferonlambda family on the innate and adaptive immune response to viral infections. Emerg Microbes Infect. 2014 Jul;3(7):e51.

8 Prokunina-Olsson L, Muchmore B, Tang W, Pfeiffer RM, Park H, Dickensheets H, et al. A variant upstream of IFNL3 (IL28B) creating a new interferon gene IFNL4 is associated with impaired clearance of hepatitis $\mathrm{C}$ virus. Nat Genet. 2013 Feb;45(2):164-71.

9 Mihm S. Activation of Type I and Type III Interferons in Chronic Hepatitis C. J Innate Immun. 2015;7(3):251-9. 